\title{
Relationship between plumage color and eggshell patterns with egg production and egg quality traits of Japanese quails
}

\author{
Ly Thi Thu Lan¹D, Nguyen Thi Hong Nhan² (D), Lam Thai Hung3 (iD), Tran Hoang Diep ${ }^{4}$ (D) Nguyen Hong Xuan ${ }^{5}$ (D), \\ Huynh Tan Loc ${ }^{6}$ a and Nguyen Trong Ngu' ${ }^{6}$
}

\begin{abstract}
1. Department of Animal Science and Veterinary Medicine, School of Agriculture and Aquaculture, Tra Vinh University, Tra Vinh City, Vietnam; 2. Department of Animal Science, College of Agriculture, Can Tho University, Can Tho City, Vietnam; 3. Department of Science and Technology, Tra Vinh Province, Tra Vinh City, Vietnam; 4. Department of Animal Science and Veterinary Medicine, Faculty of Agriculture and Food Technology, Tien Giang University, My Tho City, Vietnam;

5. Department of Food Technology, College of Food Technology and Biotechnology, Can Tho University of Technology, Can Tho City, Vietnam; 6. Department of Veterinary Medicine, College of Agriculture, Can Tho University, Can Tho City, Vietnam.

Corresponding author: Nguyen Trong Ngu, e-mail: ntngu@ctu.edu.vn

Co-authors: LTTL: thulan@tvu.edu.vn,NTHN: nthnhan@ctu.edu.vn, LTH: Ithung@tvu.edu.vn, THD: tranhoangdiep@tgu.edu.vn, NHX: nhxuan@ctuet.edu.vn, HTL: tanloc@ctu.edu.vn

Received: 30-08-2020, Accepted: 23-02-2021, Published online: 14-04-2021
\end{abstract}

doi: www.doi.org/10.14202/vetworld.2021.897-902 How to cite this article: Lan LTT, Nhan NTH, Hung LT, Diep TH, Xuan NH, Loc HT, Ngu NT (2021) Relationship between plumage color and eggshell patterns with egg production and egg quality traits of Japanese quails, Veterinary World, 14(4): 897-902.

\begin{abstract}
Aim: This study was conducted to identify the diversity of feather color and to determine the relationship between plumage color and egg yield as well as eggshell patterns and internal egg quality traits of Japanese quails.

Materials and Methods: For investigating phenotypic diversity, a total of 600 quails from five breeding farms were evaluated to record head feather, shank, and plumage color. An on-station experiment was also conducted on 360 laying quails to examine the relationship between plumage color and egg production and egg weight during 24 weeks of laying. Eggs collected during this period were also used for identifying eggshell patterns and examining their relationship with internal egg quality characteristics.

Results: Plumage color was primarily wild-type, with the highest proportion being $56.3 \%(\mathrm{p}<0.001)$. Brown color was also found at a relatively high proportion in the population (16.7\%), followed by black color $(11.3 \%)$. The egg production and laying rate of quails with wild-type and brown plumage colors also significantly $(\mathrm{p}=0.001)$ differed from those of quails with other plumage types. Egg weight was also higher in these quail groups, especially than that of quails with yellow plumage color. Four patterns of eggshell were identified, among which spotted and dark eggshells were predominant (45.2\% and $43.1 \%$, respectively); however, patterns did not affect internal egg quality characteristics.
\end{abstract}

Conclusion: Plumage color was primarily wild-type in both male and female quails. Egg yield over a 24-week laying period was superior in quails with wild-type and brown plumage colors, whereas a relationship between eggshell patterns and egg quality traits could not be established.

Keywords: egg yield, feather color, linkage, morphological characteristics.

\section{Introduction}

One of the important characteristics that help in distinguishing poultry species from other vertebrate species is the presence of feathers that provide them the ability to fly, disguise, and regulate their temperature. The change in the color of feathers in poultry has attracted the attention of ecologists and evolutionary biologists. Feather colors have been used predominantly in several areas, including sex selection, analysis of geographic differences and speciation, and the evolution of polymorphism [1]. Most of the color changes in the plumage within and between species

Copyright: Lan, et al. Open Access. This article is distributed under the terms of the Creative Commons Attribution 4.0 International License (http://creativecommons.org/licenses/by/4.0/), which permits unrestricted use, distribution, and reproduction in any medium, provided you give appropriate credit to the original author(s) and the source, provide a link to the Creative Commons license, and indicate if changes were made. The Creative Commons Public Domain Dedication waiver (http://creativecommons.org/ publicdomain/zero/1.0/) applies to the data made available in this article, unless otherwise stated. have a strong genetic component [2]. Bedhom et al. [3] mentioned that the interaction of specific gene mutations or combinations of mutations is a major cause of change in the plumage color of quails. Sezer and Tarhan [4] have also attempted to link the effects of feather color with growth characteristics in Japanese quails, and they concluded that morphological characteristics, specifically feather color, contributed significantly to the identification process as well as the selection of quail varieties.

In addition to plumage color, eggshell and its spot colors are extremely diverse. Sezer and Tekelioglu [5] demonstrated that the color of quail eggshell varies from white to blue or green, whereas Taha [6] classified quail eggs as black-spotted eggs with different sizes on brown- or gray-colored eggshell, spotless white eggs, and eggs with small black or blue spots on graybrown-colored eggshell. In contrast, Hassan et al. [7] classified quail eggs as bright eggs (without spots or very small), dotted eggs (with small spots), spotted 
eggs (with large spots), and dark eggs (with a few very large spots). The variety of eggshell color in quails has attracted several scientists. Alasahan et al. [8] also investigated the relationship between color and spots on eggshell and the internal and external qualities of eggs. Their results showed that eggshell color and color of spots had a significant effect on egg quality characteristics such as eggshell ratio, eggshell index, albumen index, yolk index, and Haugh unit. Other studies have focused on the impact of eggshell color changes on eggshell structure, egg weight reduction, and hatching parameters $[6,7]$, as well as internal and external quality characteristics of eggs.

Japanese quails (Coturnix coturnix japonica) have emerged as a research target due to their rapid growth, early sexual maturity, high egg production rate, short reproduction time, minimal requirements of space and food, easy maintenance, high resistance against several diseases in poultry, and potential for meat and eggs [9]. Despite the advantageous dominance over other poultry species, quail-breeding program has not been completely exploited, especially in the Mekong Delta of Vietnam where an approximate number of 3.19 million quails are being raised every year primarily for laying purposes [10]. One of the major issues in our knowledge regarding the selection of breeding quails is a lack of information on the relationship of phenotype with egg yield and other related traits to streamline the production aimed at an optimal profit.

Therefore, the present study was conducted to determine the relationship between plumage color and egg production as well as eggshell patterns and internal egg quality traits. The results of this study may serve as a stepping stone for the selection and hybridization of quails based on phenotypic characteristics and may also provide useful information for selecting eggs using eggshell colors.

\section{Materials and Methods}

\section{Ethical approval}

This study was carried out after obtaining approval from Can Tho University and Tra Vinh SubDepartment of Animal Health.

\section{Study period and location}

The on-station trial was conducted at the experimental farm of Tra Vinh University, Vietnam $\left(9^{\circ} 55^{\prime}\right.$ N, 106 20' E) from February to August 2019.

\section{Identification of phenotypic characteristics of Japanese quails}

The phenotypic diversity of Japanese quails raised in the Mekong Delta was investigated. Most of the farm-reared quails are introduced by breeders in the Mekong Delta in vast numbers for restocking purposes. Using the commercial lines of Japanese quails, these quail lines are thereafter generated and maintained by local breeders for egg production. In this study, five quail-breeding farms were included in the survey, among which for each farm, 30 male and 90 female quails were randomly selected to record physical features, including plumage color, head feather color, and shank color, according to the classification method described by Tsudzuki and Wakasugi [11]. A total of 600 quails (150 males and 450 females) were used in this investigation.

\section{Experimental quails and management}

On the basis of the diversity of quail feathers in the survey, quails were obtained from one quail-breeding farm consisting of quails with four popular plumage types, that is, black, brown, wildtype, and yellow, with 90 female quails per group. The laying performance of 360 quails $(167 \pm 7.8 \mathrm{~g})$ was recorded during 24 weeks of laying. Quails were individually maintained in each cage and provided a commercial diet consisting of $21 \%$ crude protein and $2850 \mathrm{kcal}$ of ME/kg from a feed company. Feed and water were available ad libitum all time, and a lighting program of $16 \mathrm{~h}$ of light/day was applied. Quails were vaccinated against Newcastle disease and infectious bursal disease (Gumboro). For the analysis of external and internal traits, eggs were collected on a given day in the $4^{\text {th }}, 8^{\text {th }}, 12^{\text {th }}, 16^{\text {th }}, 20^{\text {th }}$, and $24^{\text {th }}$ laying weeks for weighing and quality measurement.

\section{Egg measurements}

In total, 2160 eggs were included for recording egg weight and shell pattern during the experimental period. The categorical classification of the eggshell patterns of Japanese quails was based on Hassan et al. [7]. For interior quality characteristics, one-fourth of the eggs (540 eggs) were analyzed. A digital display caliper was used to measure the width, length, yolk diameter, and albumen length and width of the eggs; yolk weight was measured to an accuracy of $0.01 \mathrm{~g}$, and the proportion of this parameter was expressed in percentage corresponding to egg weight. Yolk color was determined using the La Roche scale scoring from 1 to 15 [12]. Albumen weight was calculated by subtracting the yolk and shell weight from the whole egg weight. These data were used to determine the external and internal quality characteristics of eggs using the following formulas [13]: Shape index $(\%)=($ Width $[\mathrm{mm}] /$ Length $[\mathrm{mm}]) \times 100$; Shell ratio $(\%)=($ Shell weight $[\mathrm{g}] /$ Egg weight $[\mathrm{g}]) \times 100$; Albumen weight $(\mathrm{g})=$ Egg weight $-($ Shell weight + Yolk weight); Yolk ratio $(\%)=($ Yolk weight $[\mathrm{g}] /$ Egg weight $[\mathrm{g}]) \times 100$; Albumen ratio $(\%)=($ Albumen weight $[\mathrm{g}] /$ Egg weight $[\mathrm{g}]) \times 100$; Yolk index $(\%)=($ Yolk height $[\mathrm{mm}] /$ Yolk diameter $[\mathrm{mm}]) \times 100$; Albumen index $(\%)=($ Albumen height $[\mathrm{mm}] /[$ (Albumen length $[\mathrm{mm}]+$ Albumen width $[\mathrm{mm}]) / 2]) \times 100 ;$ Haugh unit $=100 \log$ (Albumen height $[\mathrm{mm}]+7.57-1.7 \times$ Egg weight $[\mathrm{g}]^{0.37}$.

\section{Statistical analysis}

All data were subjected to statistical analysis using the Minitab 16.2 software (State College, PA, USA) [14]. The Chi-square test was used to evaluate the distribution of morphological characteristics, 
and a general linear model $\mathrm{Y}_{\mathrm{ij}}=\mu+\mathrm{W}_{\mathrm{i}}+\mathrm{e}_{\mathrm{ij}}$ was used to evaluate the relationship between phenotypes and production and quality traits, where $\mathrm{Y}_{\mathrm{ij}}$ is the phenotypic value of the traits, $\mu$ is the overall mean, $\mathrm{W}_{\mathrm{i}}$ is the effect of plumage color (black, brown, wild-type, and yellow), and $\mathrm{e}_{\mathrm{ij}}$ is the random error.

\section{Results}

\section{Phenotypic characteristics}

The feather color of Japanese quails in the Mekong Delta was diverse and distributed differently between female and male quails as well as between body parts as shown in Table-1. Regarding head feather color, yellow accounted for the highest proportion $(54.0 \%)$ in male quails $(\mathrm{p}=0.001)$, whereas in female quails, black plumage color $(39.1 \%, \mathrm{p}=0.001)$ was predominant over other colors, although the proportion of male quails with this color was the lowest $(2.0 \%)$. Furthermore, gray color was found in a high proportion of male and female quails, with $31.3 \%$ and $23.1 \%$, respectively. Moreover, plumage color was primarily wild-type for both male (44.7\%) and female $(60.2 \%)$ quails, with the highest average rate being $56.3 \%(p=0.001)$. Brown color was also identified at a relatively high rate in the quail population (16.7\%). Coincidentally, black color had the lowest proportion in the population (11.3\%). In addition, for shank color, the highest proportion was found for pinkish-brown $(62.7 \%)$, followed by yellow (24.3\%) for both male and female quails. Although orangish-gray color appeared at a high rate $(29.3 \%)$ in the population of male quails compared with yellow color $(3.3 \%)$ $(p=0.001)$, it still accounted for the lowest percentage of the total population surveyed.

\section{Relationship between plumage color and egg production}

Egg production was found to have a close relationship with plumage color (Table-2). During all the recorded laying periods, a significant difference ( $p=0.001$ ) was observed between the types of brown and wild-type plumage colors and the other types of black and yellow colors in the laying weeks. In general, there were significant differences in the two types of brown and wild-type plumage colors on the average number of eggs (150.4 and 155.4, respectively) and laying rate ( $89.5 \%$ and $92.5 \%$, respectively). Egg weight was also higher in these quail groups, especially in quails with the yellow plumage color. Furthermore, although the mean shape index significantly differed in the $12^{\text {th }}$ week between all types of quails, the average value observed during the 24 weeks of laying was similar, ranging from $75.6 \%$ to $76.7 \%$.

\section{Effects of eggshell patterns on egg quality characteristics}

In terms of eggshell patterns, spotted and dark eggs accounted for a higher proportion $(45.2 \%$ and $43.1 \%$, respectively) than bright and little-spotted eggs (Table-3); however, the patterns did now show any relationship with internal egg quality traits $(\mathrm{p}>0.05)$.

\section{Discussion}

Japanese quails in the Mekong Delta were found to be quite diverse in terms of plumage colors. Mishra et al. [15] also reported that Japanese quails had breast colors such as white, brown, and white brown, wherein the presence of white color was due to a new mutation of dominant gene activity at a locus in the genome. According to a previous study conducted by Tsudzuki and Wakasugi [11], the plumage of quails consists of colored bands arranged from tail to head with some common colors such as gray, black, white-gray, brown, wild-type, and yellow. Wild-type was found to be the most popular plumage color in the quail population, and different feather colors were also identified between male and female quails. The dominant population of wild-type quails can be explained by the fact

Table-1: Distribution of feather color in breeding Japanese quails raised in the Mekong Delta.

\begin{tabular}{|c|c|c|c|c|c|c|}
\hline \multirow[t]{2}{*}{ Color } & \multicolumn{2}{|c|}{ Male $(n=150)$} & \multicolumn{2}{|c|}{ Female $(n=450)$} & \multicolumn{2}{|c|}{ Total $(n=600)$} \\
\hline & Number & Ratio (\%) & Number & Ratio (\%) & Number & Ratio (\%) \\
\hline \multicolumn{7}{|l|}{ Head } \\
\hline Black & 3 & $2.0^{d}$ & 176 & $39.1^{\mathrm{a}}$ & 179 & $29.8^{a b}$ \\
\hline Black stripes & 19 & $12.7^{c}$ & 41 & $9.1^{\mathrm{d}}$ & 60 & $10.0^{c}$ \\
\hline Gray & 47 & $31.3^{b}$ & 104 & $23.1^{\mathrm{c}}$ & 151 & $25.2^{b}$ \\
\hline Yellow & 81 & $54.0^{a}$ & 129 & $28.7^{b c}$ & 210 & $35.0^{a}$ \\
\hline p-value & & 0.001 & & 0.001 & & 0.001 \\
\hline \multicolumn{7}{|l|}{ Plumage } \\
\hline Black & 26 & $17.3^{\mathrm{b}}$ & 42 & $9.3^{d}$ & 68 & $11.3^{c}$ \\
\hline Brown & 36 & $24.0^{\mathrm{b}}$ & 64 & $14.2^{c}$ & 100 & $16.7^{\mathrm{b}}$ \\
\hline Wild-type & 67 & $44.7^{a}$ & 271 & $60.2^{a}$ & 338 & $56.3^{a}$ \\
\hline Yellow & 21 & $14.0^{\mathrm{b}}$ & 73 & $16.2^{\mathrm{bc}}$ & 94 & $15.7^{\mathrm{bc}}$ \\
\hline p-value & & 0.001 & & 0.001 & & 0.001 \\
\hline \multicolumn{7}{|l|}{ Shank } \\
\hline Orangish-gray & 44 & $29.3^{b}$ & 34 & $7.6^{c}$ & 78 & $13.0^{c}$ \\
\hline Pinkish-brown & 101 & $67.3^{a}$ & 275 & $61.1^{\mathrm{a}}$ & 376 & $62.7^{a}$ \\
\hline Yellow & 5 & $3.3^{c}$ & 141 & $31.3^{b}$ & 146 & $24.3^{b}$ \\
\hline p-value & & 0.001 & & 0.001 & & 0.001 \\
\hline
\end{tabular}

$a, b, c, d$ Means bearing different superscripts within a column differ significantly $(p<0.05)$ 
Table-2: Relationship between plumage colors and egg production traits.

\begin{tabular}{|c|c|c|c|c|c|c|c|c|}
\hline \multirow[t]{2}{*}{ Parameters } & \multirow{2}{*}{$\begin{array}{l}\text { Plumage } \\
\text { color }\end{array}$} & \multicolumn{7}{|c|}{ Laying weeks } \\
\hline & & $1-4$ & $5-8$ & $9-12$ & $13-16$ & $17-20$ & 21-24 & $1-24$ \\
\hline \multirow{5}{*}{$\begin{array}{l}\text { Egg } \\
\text { production }\end{array}$} & Black & $17.2 \pm 0.54^{b}$ & $21.2 \pm 0.38^{\mathrm{b}}$ & $22.6 \pm 0.42^{b}$ & $22.4 \pm 0.49^{b}$ & $21.2 \pm 0.47^{\mathrm{b}}$ & $19.1 \pm 0.65^{\mathrm{b}}$ & $124.8 \pm 1.54^{b}$ \\
\hline & Brown & $20.3 \pm 0.54^{a}$ & $24.0 \pm 0.36^{a}$ & $26.5 \pm 0.39^{a}$ & $26.6 \pm 0.46^{a}$ & $26.5 \pm 0.44^{a}$ & $26.4 \pm 0.61^{a}$ & $150.4 \pm 1.45^{a}$ \\
\hline & Wild-type & $22.1 \pm 0.54^{a}$ & $24.8 \pm 0.37^{a}$ & $27.4 \pm 0.40^{\mathrm{a}}$ & $27.3 \pm 0.47^{a}$ & $26.9 \pm 0.45^{\mathrm{a}}$ & $26.8 \pm 0.62^{\mathrm{a}}$ & $155.4 \pm 1.48^{a}$ \\
\hline & Yellow & $17.7 \pm 0.54^{b}$ & $21.3 \pm 0.41^{b}$ & $22.4 \pm 0.44^{b}$ & $20.7 \pm 0.52^{b}$ & $21.2 \pm 0.49^{b}$ & $19.0 \pm 0.69^{b}$ & $122.1 \pm 1.64^{b}$ \\
\hline & $\mathrm{p}$-value & 0.001 & 0.001 & 0.001 & 0.001 & 0.001 & 0.001 & 0.001 \\
\hline \multirow{5}{*}{$\begin{array}{l}\text { Laying } \\
\text { rate }(\%)\end{array}$} & Black & $59.9 \pm 2.03^{b}$ & $75.5 \pm 1.36^{b}$ & $81.2 \pm 1.49^{b}$ & $79.8 \pm 1.77^{b}$ & $75.7 \pm 1.69^{b}$ & $68.3 \pm 2.32^{b}$ & $74.3 \pm 0.92^{b}$ \\
\hline & Brown & $72.7 \pm 1.90^{\mathrm{a}}$ & $85.6 \pm 1.27^{a}$ & $94.8 \pm 1.34^{a}$ & $95.1 \pm 1.65^{a}$ & $94.6 \pm 1.58^{a}$ & $94.1 \pm 2.17^{a}$ & $89.5 \pm 0.86^{a}$ \\
\hline & Wild-type & $79.2 \pm 1.95^{a}$ & $88.7 \pm 1.30^{a}$ & $97.9 \pm 1.43^{\mathrm{a}}$ & $97.5 \pm 1.67^{a}$ & $95.9 \pm 1.61^{a}$ & $95.8 \pm 2.22^{\mathrm{a}}$ & $92.5 \pm 0.88^{a}$ \\
\hline & Yellow & $62.7 \pm 2.14^{b}$ & $76.2 \pm 1.43^{b}$ & $80.5 \pm 1.57^{b}$ & $74.3 \pm 1.86^{b}$ & $75.2 \pm 1.78^{b}$ & $68.7 \pm 2.45^{b}$ & $72.6 \pm 0.97^{b}$ \\
\hline & p-value & 0.001 & 0.001 & 0.001 & 0.001 & 0.001 & 0.001 & 0.001 \\
\hline \multirow{5}{*}{$\begin{array}{l}\text { Egg } \\
\text { weight ( } g \text { ) }\end{array}$} & Black & $11.3 \pm 0.12^{\mathrm{b}}$ & $11.7 \pm 0.10^{\mathrm{ab}}$ & $11.9 \pm 0.10$ & $11.7 \pm 0.11^{\mathrm{ab}}$ & $11.5 \pm 0.15$ & $11.7 \pm 0.10$ & $11.6 \pm 0.09^{a b}$ \\
\hline & Brown & $11.7 \pm 0.12^{\mathrm{a}}$ & $12.0 \pm 0.09^{a}$ & $12.0 \pm 0.10$ & $12.0 \pm 0.10^{a}$ & $11.8 \pm 0.14$ & $12.0 \pm 0.10$ & $11.9 \pm 0.08^{a}$ \\
\hline & Wild-type & $11.8 \pm 0.12^{a}$ & $11.9 \pm 0.10^{\mathrm{ab}}$ & $11.9 \pm 0.10$ & $11.9 \pm 0.10^{\mathrm{a}}$ & $11.6 \pm 0.14$ & $11.9 \pm 0.10$ & $11.8 \pm 0.09^{a}$ \\
\hline & Yellow & $11.3 \pm 0.13^{b}$ & $11.6 \pm 0.11^{\mathrm{b}}$ & $11.7 \pm 0.11$ & $11.5 \pm 0.11^{b}$ & $11.3 \pm 0.16$ & $11.6 \pm 0.11$ & $11.5 \pm 0.10^{\mathrm{b}}$ \\
\hline & p-value & 0.002 & 0.018 & 0.128 & 0.011 & 0.057 & 0.096 & 0.004 \\
\hline \multirow{5}{*}{$\begin{array}{l}\text { Shape } \\
\text { index (\%) }\end{array}$} & Black & $75.1 \pm 0.72$ & $74.5 \pm 1.17$ & $74.8 \pm 0.59^{b}$ & $74.9 \pm 0.72$ & $74.1 \pm 1.03$ & $75.9 \pm 0.34$ & $75.6 \pm 0.43$ \\
\hline & Brown & $77.1 \pm 0.66$ & $76.2 \pm 1.07$ & $77.3 \pm 0.58^{\mathrm{a}}$ & $76.5 \pm 0.65$ & $75.1 \pm 0.94$ & $76.7 \pm 0.30$ & $76.7 \pm 0.42$ \\
\hline & Wild-type & $76.0 \pm 0.68$ & $75.3 \pm 1.11$ & $77.1 \pm 0.58^{\mathrm{a}}$ & $76.3 \pm 0.68$ & $75.1 \pm 0.97$ & $76.7 \pm 0.32$ & $76.2 \pm 0.42$ \\
\hline & Yellow & $76.0 \pm 0.76$ & $73.6 \pm 1.23$ & $74.7 \pm 0.60^{b}$ & $75.6 \pm 0.75$ & $74.0 \pm 1.08$ & $76.8 \pm 0.35$ & $75.6 \pm 0.43$ \\
\hline & $p$-value & 0.233 & 0.439 & 0.001 & 0.396 & 0.764 & 0.220 & 0.237 \\
\hline
\end{tabular}

$a, b$ Means bearing different superscripts within a column differ significantly $(p<0.05)$

Table-3: Internal quality characteristics of eggs from different eggshell patterns.

\begin{tabular}{lccccc}
\hline Parameters & \multicolumn{2}{c}{ Eggshell patterns } & Dark \\
\cline { 2 - 4 } & Bright & Dotted & Spotted & Dalue \\
\hline Number of eggs & 108 & 145 & 976 & 931 & \\
Proportion & $5.0^{\mathrm{d}}$ & $6.7^{\mathrm{c}}$ & $45.2^{\mathrm{a}}$ & $43.1^{\mathrm{ab}}$ & \\
Egg characteristics & & & & \\
Shell weight (g) & $1.68 \pm 0.05$ & $1.62 \pm 0.04$ & $1.64 \pm 0.02$ & $1.62 \pm 0.02$ & 0.649 \\
Shell ratio (\%) & $14.9 \pm 0.45$ & $14.2 \pm 0.39$ & $14.2 \pm 0.15$ & $14.3 \pm 0.15$ & 0.542 \\
Yolk weight (g) & $3.51 \pm 0.08$ & $3.58 \pm 0.07$ & $3.59 \pm 0.03$ & $3.58 \pm 0.03$ & 0.873 \\
Albumin weight (g) & $6.15 \pm 0.15$ & $6.3 \pm 0.13$ & $6.30 \pm 0.05$ & $6.17 \pm 0.05$ & 0.216 \\
Yolk ratio (\%) & $31.0 \pm 0.66$ & $31.2 \pm 0.57$ & $31.1 \pm 0.22$ & $31.5 \pm 0.22$ & 0.591 \\
Albumin ratio (\%) & $54.0 \pm 0.96$ & $54.7 \pm 0.83$ & $54.6 \pm 0.32$ & $54.2 \pm 0.33$ & 0.797 \\
Yolk/albumin ratio (\%) & $58.8 \pm 2.02$ & $58.6 \pm 1.75$ & $57.7 \pm 0.67$ & $58.8 \pm 0.70$ & 0.722 \\
Yolk index (\%) & $40.9 \pm 1.12$ & $40.9 \pm 0.97$ & $40.6 \pm 0.37$ & $40.3 \pm 0.38$ & 0.907 \\
Albumin index (\%) & $9.63 \pm 0.43$ & $9.53 \pm 0.37$ & $9.10 \pm 0.14$ & $9.18 \pm 0.15$ & 0.516 \\
Haugh unit & $88.7 \pm 0.84$ & $88.9 \pm 0.72$ & $87.5 \pm 0.28$ & $87.7 \pm 0.28$ & 0.201 \\
\hline
\end{tabular}

$a, b$ Means bearing different superscripts within a row differ significantly $(p<0.05)$

that the wild-type group had lower mortality rates and higher values of internal and external quality characteristics of eggs than others, including the white, dark brown, and golden plumage color groups [16]. Another study reported that wild-type Japanese quails had significantly higher slaughter weight than quails of light brown type [15]. Although some studies have shown that white quails had the heaviest body weight with the best carcass traits and meat quality [17-19], this color was not found in the present study. Altogether, it is necessary to consider the favorable characteristics of wild-type quails to improve quail production in the Mekong Delta.

The differences in some phenotypic traits of quails, including egg production, laying rate, egg weight, and shape index, from the four types of plumage colors were also determined in this study. Interestingly, they exhibited a close relationship with egg yield during the 24-week laying period. The values of these traits for quails with brown and wild-type plumage colors were consistently higher than those for quails with black and yellow plumage colors. Supporting this finding, egg production was found to differ significantly according to different quail phenotypes [20,21]. Egg weight was also affected by the diversity of plumage colors, where eggs laid by quails with yellow plumage were lower in weight than those laid by quails with other plumage patterns. In the present study, the brown Japanese quail was superior in terms of egg weight, which is consistent with some previously reported studies [21-23]. These findings support the results obtained by Ashok and Reddy [24] who reported that there were significant differences in egg weight between various types of quails. Overall, these results may be beneficial to select appropriate breeding programs for egg-laying quails in the long term. 
Four eggshell color groups were recorded in the present study, among which spotted and dark eggs predominated in the population; these findings were consistent with those of Sezer and Tekelioglu [5]. Basically, egg color forms when it travels through the hen's oviduct. When the eggshell begins to form, epithelial cells at the surface of the eggshell gland (uterus) begin to synthesize color pigments [25]. The previous studies $[26,27]$ have also confirmed that eggshell color is a genetic transformation of pigments on the egg surface in the uterus. In addition, Alasahan et al. [28] classified the color of eggshells into five different groups, including black-spotted gray-white, green-spotted gray-white, scattered brown-spotted gray-brown, brown-spotted light-green, and small brown-spotted gray-brown. However, they also indicated that the effect of eggshell color on egg weight, eggshell mass, albumen weight, and yolk weight was not statistically significant. It was also pointed out that the shell color of Japanese quail eggs, blue or spotted, did not appear to affect their quality [29]; however, it can affect the hatching results and body weight of the obtained chicks of Japanese quails. Nevertheless, Taha [6] reported higher egg weight, egg length, and egg width in the black-spotted quail group than in the blue-spotted quail group. It is worth noting that the determination of the best type of eggshell colors in terms of egg quality is controversial among the published data. In the present study, although spotted and dark eggshells were predominant patterns, the relationship between eggshell patterns and internal egg quality traits could not be established.

\section{Conclusion}

The plumage color of Japanese quails raised in the Mekong Delta of Vietnam was primarily wildtype in both male and female populations. The differences in these color patterns affected egg yield over a 24-week laying period, with superior values in quails with wild-type and brown plumage colors, but no relationship was identified between eggshell patterns and egg quality traits.

\section{Authors' Contributions}

LTTL, NTHN, and NTN designed the experimental procedures. LTTL, NTHN, LTH, THD, and NHX performed the experiments. LTTL, NTHN, HTL, and NTN interpreted the data and prepared the manuscript. All authors read and approved the final manuscript.

\section{Acknowledgments}

This study was funded by Vietnam National Foundation for Science and Technology Development (NAFOSTED) under grant number 106-NN.05-2013.12.

\section{Competing Interests}

The authors declare that they have no competing interests.

\section{Publisher's Note}

Veterinary World remains neutral with regard to jurisdictional claims in published institutional affiliation.

\section{References}

1. Roulin, A. (2004) The evolution, maintenance and adaptive function of genetic colour polymorphism in birds. Biol. Rev., 79(4): 815-848.

2. Mundy, N.I. (2005) A window on the genetics of evolution: $\mathrm{MC1R}$ and plumage colouration in birds. Proc. Biol. Sci., 272(1573): 1633-1640.

3. Bed'hom, B., Vaez, M., Coville, J.L., Gourichon, D., Chastel, O., Follett, S., Burke, T. and Minvielle, F. (2012) The lavender plumage colour in Japanese quail is associated with a complex mutation in the region of MLPH that is related to differences in growth, feed consumption and body temperature. BMC Genomics, 13(1): 1-10.

4. Sezer, M. and Tarhan, S. (2005) Model parameters of growth curves of three meat-type lines of Japanese quail. Czech J. Anim. Sci., 50(1): 22-30.

5. Sezer, M. and Tekelioglu, O. (2009) Quantification of Japanese quail eggshell colour by image analysis. Biol. Res., 42(1): 99-105.

6. Taha, A.E. (2011) Analyzing of quail eggs hatchability, quality, embryonic mortality and malpositions in relation to their shell colors. Online J. Anim. Feed Res., 1(6): 267-273.

7. Hassan, H.A., El-Nesr, S., Osman, A. and Arram, G. (2013) Ultrastructure of eggshell, egg weight loss and hatching traits of Japanese quail varying in eggshell color and pattern using image analysis. Egypt. Poult. Sci. J., 34(I): 1-17.

8. Alaşahan, S., Çopur, G.A., Canoğulları, S. and Baylan, M. (2015) Determination of some external and internal quality traits of Japanese quail (Coturnix coturnix japonica) eggs on the basis of eggshell colour and spot colour. Eurasian $J$. Vet. Sci., 31(4): 235-241.

9. Akpa, G., Kaye, J., Adeyinka, I. and Kabir, M. (2008) The relationships between laying age and repeatability of egg quality traits in Japanese quails (Coturnix coturnix japonica). Int. J. Poult. Sci., 7(6): 555-559.

10. Vietnam, G.S.O. (2020) Vietnam Livestock Statistics: Number and Products of Animals and Poultry, Department of Animal Husbandry.

11. Tsudzuki, M. and Wakasugi, N. (1987) "Pansy": A plumage color mutant in Japanese quail. J. Poult. Sci., 24(6): 327-335.

12. Lokaewmanee, K., Mompanuon, S., Khumpeerawat, P. and Yamauchi, K. (2009) Effects of dietary mulberry leaves (Morus alba L.) on egg yolk color. J. Poult. Sci., 46(2): 112-115.

13. Nazligül, A., Türkyilmaz, K. and Bardakçioğlu, H.E. (2001) A study on some production traits and egg quality characteristics of Japanese quail. Turk. J. Vet. Anim. Sci., 25(6): 1007-1013.

14. Minitab. (2010) Minitab Reference Manual, Release 16.2.1 for Windows. Minitab Inc., United States.

15. Mishra, S.K., Khan, A.A., Narayan, R., Singh, S.P., Pratap, S.O., Saxena, D., Chaudhuri, D. (2011) Inheritance of plumage colour variations in a large flock of Japanese quail. Br. Poult. Sci., 52(6): 686-693.

16. Inci, H., Sogut, B., Sengul, T., Sengul, A.Y. and Taysi, M.R. (2015) Comparison of fattening performance, carcass characteristics, and egg quality characteristics of Japanese quails with different feather colors. Rev. Bras. Zootec., 44(11): 390-396.

17. Nasr, M.A., Ali, E.S.M. and Hussein, M.A. (2017) Performance, carcass traits, meat quality and amino acid profile of different Japanese quails strains. J. Food Sci. Technol., 54(13): 4189-4196.

18. Dash, S.K., Naik, S., Dubey, P.P., Malhotra, P. and 
Bansal, B.K. (2018) Effect of plumage colour and estimation of variance components of bi-weekly growth traits in Japanese quail (Coturnix coturnix japonica). Indian J. Anim. Sci., 88(10): 1193-1196.

19. Al-Kafajy, F.R., Al-Shuhaib, M.B.S., Al-Jashami, G.S. and Al-Thuwaini, T.M. (2018) Comparison of three lines of Japanese quails revealed a remarkable role of plumage color in the productivity performance determination. J. World Poult. Res., 8(4): 111-119.

20. Rahman, M., Rasul, K. and Islam, M. (2010) Comparison of the productive and reproductive performance of different color mutants of Japanese quails (Coturnix japonica). In: Proceedings of the Annual Research Review Workshop. BLRI, Savar, Dhaka, Bangladesh. p50-56.

21. Cahyadi, M., Fauzy, R. and Dewanti, R. (2019) Egg production traits and egg quality characteristics in black and brown plumage color lines of Japanese quail. Poult. Sci. J., 7(2): 179-184.

22. Chimezie, V., Fayeye, T., Ayorinde, K. and Adebunmi, A. (2017) Phenotypic correlations between egg weight and some egg quality traits in three varieties of Japanese quail (Coturnix coturnix japonica). Agrosearch, 17(1): 44-53.

23. Hassan, A.M., Mohammed, D.A., Hussein, K.N. and
Hussen, S.H. (2017) Comparison among three lines of quail for egg quality characters. Sci. J. Univ. Zakho, 5(4): 296-300.

24. Ashok, A. and Reddy, P.M. (2010) Evaluation of reproductive traits in three strains of Japanese quail. Vet. World, 3(4): 169-170.

25. Butcher, G. and Miles, R. (1995) Factors causing poor pigmentation of brown-shelled eggs. In: Cooperative Extension Service Fact Sheet VM94. The Institute of Food and Agricultural Sciences. University of Florida, Gainesville.

26. King'ori, A. (2012) Poultry egg external characteristics: Egg weight, shape and shell colour. Res. J. Poult. Sci., 5(2): 14-17.

27. Holbrook, D. (2014) How to Determine a Chick's Gender Before it Hatches, Animals Diamond Media, Animals Index.

28. Alasahan, S., Akpinar, G.C., Canogullari, S. and Baylan, M. (2016) The impact of eggshell colour and spot area in Japanese quails: II. Slaughter and carcass characteristic. Rev. Bras. Zootec., 45(9): 509-517.

29. Drabik, K., Batkowska, J., Vasiukov, K. and Pluta, A. (2020) The Impact of eggshell colour on the quality of table and hatching eggs derived from Japanese quail. Animals, 10(2): 264

$* * * * * * * *$ 